\title{
Commentary
}

\section{The role of districts in supporting school leaders' instructional leadership: a view and experience from a developing country}

Introduction

The downfall of Suharto's New Order regime in 1998 brought a fundamental change in the way Indonesia, the biggest country in South-East Asia spanning three time zones, was ruled. The Reform era started after the fall of the Suharto government in May 1998 and continued up until approximately a decade ago (Lindsey, 2018a,b). Nevertheless, the reforms are still underway.

In fact, some of the most significant reforms in Indonesia's education system occurred in the last 17 years. Such reforms include the decentralization of education sector functions to the district level, an increased allocation of 20 percent of the national budget on education, implementation of the 2005 Teacher Law, and increased aid to schools with the School Operational Assistance Grant (Bantuan Operasional Sekolah) program (The World Bank, 2018). This Reform era ended the prior governance model of centralization, which actually began in the Dutch colonial era in the nineteenth century. This great change in terms of size, speed and scope of governance, referred to as the "big bang" decentralization model (Bennet, 2010), served as the beginning of democracy in Indonesia. This new policy was initiated through two laws made effective on January 1, 2001, called the Laws on Local Government, and the Laws on Fiscal Balance. These developments were described as "one of the most radical decentralization programs attempted anywhere in the world" (Aspinal and Fealy, 2003, p. 3). As a result, education, and other public sectors in Indonesia, became the responsibility of district governments.

At that time, we were working as young teachers in public schools, and young lecturers in public universities. Like many other Indonesian educators, we felt that the idea of educational decentralization, where the main argument for decentralization was that it brings the governments closer to the people with a promise to serve the public more efficiently and effectively, seemed appropriate to the realities of our situation. Our initial response to the new laws was one of excitement. As educators, we were interested in the changes that were proposed. In particular, we were interested in the shift of power from central government to district level jurisdictions, bypassing the province level. Yet, we strove to understand: what was actually proposed? What was the rationale? What were the envisaged implications for districts? To what extent were districts and schools clear about the reform and their implications? These and many more questions were asked by educators, including ourselves. Our questions represented the considerable interest of educators in Indonesia to help a country that was badly impacted by the Asian financial crisis before the Reform era. In relevance to the reform the educational decentralization seemed to offer certain promises and possibilities for educators, including that of improving educational quality.

Fast forward to recent time - the articles in this special edition of the Journal of Educational Administration discuss the district's role in supporting school leaders' instructional leadership and provide perspectives about changes happening at the district level. The focus of this special issue reminds us of our country's situation 18 years ago in which a big social experiment was performed in Indonesia, particularly in the education sector, with the promise to improve it. From these seven articles, we found that policies associated with instructional leadership vary from one country to another or even from one district to another within a country. Furthermore, the articles describe different

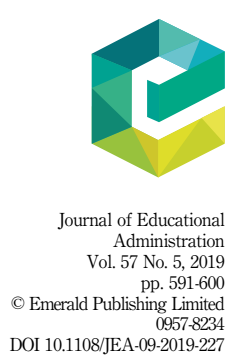


JEA

57,5

socio-cultural-political environments, all of which are from first World countries: three from the USA, and one each from Scandinavia, Canada, Australia, Scotland and UK. The development of the districts' roles in improving instructional leadership practice at the school level, as framed in this issue, informs readers about the complexities and challenges of this work. The studies give fresh perspective on the strategies and approaches that can be used by government and non-government organizations in developing countries.

This commentary article attempts to view the practices reported on by the contributors in developed countries, and their applicability to the Indonesian context, in two themes. The first part of the article will discuss practices at the district level, which involve school supervisors and district education office staff, and the second part will discuss conditions at the school level, where principals exercise their instructional leadership.

\section{A view from the district level}

The district education offices undoubtedly play a role in the public school system. Supporting principals appropriately to facilitate effective teaching and learning in classrooms is a district office's role. Experiences described in this section show the progress that is happening among developed countries relates to one developing country's practice. Five out of the seven articles explicitly reported on the changing nature of the district level's role in this special issue. Chapman's (2019) article illustrated that good orchestration of effort from the state and district levels in Scotland can help underperforming schools to achieve both merit ratings and to close the attainment gap. He noted that resource allocations to schools were not always based on need, which indicates that robust remedial measures, particularly at the local authority level, were required in order to maintain equality in the school system. However, the experience described in Indonesian decentralization reports displays a different picture.

Certainly, decentralization in Indonesia was welcomed by district elites - people in major offices and education district offices; suddenly, their power and authority increased in one night. "They became dominant education authorities which control all public schools and teachers in their territories" (Zamjani, 2016, p. 3). When the parliament passed a new law about national education in 2003, the role of the Indonesia Ministry of Education and Culture (MoEC) adjusted to the new realities of educational decentralization. It became an institution that established educational standards and guidelines (Asikin-Garmager, 2017). One of the main objectives was to ease wide regional disparities between urban districts (municipalities) and rural districts (regents), and also between districts that have abundant natural resources and districts that have few, which can be a potential threat to national unity. For this purpose, the MoEC became very busy releasing regulations in all aspects of education, and tried to make sure that the standards were maintained at the local level. However, districts mostly neglected the standards: "Many of the MoEC's regulations of such things as school fees, principals' appointment, teacher management and classroom size were evaded because they were at odds with local interests" (Zamjani, 2016, p. 4). This clearly shows that the central government's goals were not designed hand in hand with district goals. One of the main reasons for this is informed by the report from the Analytical and Capacity Development Partnership (ACDP, 2013, p. 17) showing the realities of the local district capacity, where "a significant number of district education heads, supervisors [...] did not have an adequate understanding of the content of the regulations."

In Norway and Sweden, with a similar move of decentralization, Aas and Paulsen (2019) explained that the reason why a large portion of responsibilities and authorities were transferred from the state to the municipal level was to improve schools' instructional leadership. The "Benchlearning" program explained in their study in Scandinavian 
countries resulted in seven areas of new practices that changed the roles of many parties at the school level, leading to student learning improvement. With the decentralization efforts in Indonesia, meanwhile, a few fruitful practices started to appear. In the beginning of the Reform era, districts such as Musi Banyuasin in Sumatera, Sinjai in Sulawesi, Bontang in Kalimantan and Jembrana in Bali made significant changes. All of them initiated a free school policy, which abolished tuition fees previously regularly collected by the schools from parents. This practice had long been established in the public school system in Indonesia since the 1950s (Fitriah et al., 2013; Sumintono et al., 2014).

Among these districts, the most remarkable change from the educational decentralization efforts was in Jembrana, where the policy was followed with additional welfare for teachers, and a requirement of transparency and accountability of school financial reports (Nugroho, 2008). As a result of these changes, Jembrana, the poorest district in Bali, had the highest increase in school final exam results (Suprana, 2009). The educational decentralization that led Jembrana to this result made others believe that education decentralization could actually make a difference. The central point of this change was the district major himself. He had analyzed the district budget, and decided that the local government could give full support for free education to all in the district. This change positively affected the day-to-day work of schooling; Jembrana's teachers focused more on teaching and students' learning, and principals ensured this expectation was met in each classroom (Nugroho, 2008; Suprana, 2009). Following suit, big districts including Surabaya (Zamjani, 2016), and provinces including Jakarta adopted the policy. Such a policy is not unique anymore, especially since the launch of the free school program in 2005 that ensures a basic level of education (for students years one to nine) now is fully supported by the central government (Fitriah et al., 2013).

In a well written article about fundamental change in the role of principal supervisors, Honig and Rainey (2019) described a shift from "evaluating principals and operational issues" to "helping their principals grow as instructional leaders." Obviously, the change which started at the district level actually started with a change in the bureaucratic structure of central office, where the old organizational structure was replaced with a new arrangement. This shift was followed by a good recruitment system and extensive training for principal supervisors, which facilitated the transformation of school inspectors to principal supervisors focused on coaching and mentoring principals, thereby motivating a change in the role of the principal as well. To make it a success, trust and collaboration between principal supervisors and principals needed to be well established, and each party needed to contribute to the partnership, which was also emphasized by Thessin (2019) in this issue too.

In the same context, Thessin's (2019) article highlighted the antecedents required by both supervisors and principals and their essential contributions to an effective partnership, and thus to instructional leadership effectiveness. One of the key criteria to establish an effective partnership is the presence of trust by each party in the partnership. Principal supervisors need to consider how to provide support and establish collegiality to build trust. Trust and other conditions, such as the skillfulness and credibility of the principal supervisors, as well as the qualities of self-regulated learners of the principals, need to be in place. These antecedents will help principal supervisors and principals build a harmonious partnership that will finally lead to a joint commitment to instructional leadership effectiveness (Thessin, 2019). Trust in the relationship between principal supervisors and principals will also help improve learning outcomes. In contrast, a mistrusting relationship between stakeholders (e.g., district leaders, principal supervisors, principals and teachers) will decrease school leadership effectiveness.

This finding in developed countries, as illustrated by Honig and Rainey (2019) and Thessin (2019), stands in contrast to the Indonesian experience. Regarding school 
JEA

57,5

supervisors (essentially, principal supervisors) first, up until now, Indonesia has had a legacy from the Dutch colonial government of school inspectors. School inspectors assess aspects of supervision (Arsyad, 2017), one of which is the personalities of school personnel (principals and teachers) in terms of their capacity, honesty and loyalty (Sumintono et al. in press). This role is still the same even after the independence of Indonesia to date, where the supervisors' report really influences the decision for the appointment of principals in schools. Second, during the Reform era, the selection and appointment of school supervisors were placed in the hand of local district governments. Compared to school principals, supervisor positions in Indonesia were less prestigious. Usually the district governments appointed ex-principals, or senior teachers who had not obtained posts as principals, as supervisors. Certainly, in merely fulfilling an educational bureaucracy role, school supervisors then placed more emphasis on evaluation and compliance monitoring with teachers and principals.

A recent report from ACDP (2013) of a survey on school supervisors nationally revealed many interesting findings. In the study, 903 supervisors from many regions in Indonesia participated (62 of them were also involved in the qualitative section of the study), and the opinion and perception of principals $(n=4,070)$, teachers $(n=3,536)$, and heads of district education offices $(n=94)$ regarding the supervisors were obtained. Indonesian school supervisors rated themselves most competent in the dimensions of personality and in social aspects, but they were least competent in the dimensions of research, development and supervision. In relation to the supervisors' lack of competence in research and development, it was found that large percentages of the supervisors "had not participated in regular training at any level over the last three years" (ACDP, 2013, p. 12).

When asked about their strengths, managerial supervision was regarded by the supervisors as their greatest area of strength. This finding was supported by the opinions of the district education heads and by school principals. It is clear that among those three parties (supervisors, district education heads and school principals), school management was the most crucial aspect of the work, and understandably so as supervisors prioritized evaluation and compliance. On top of that, the principals, therefore, who prioritized school management, could not be expected to be interested in instructional leadership.

In Rigby et al.'s (2019) article, authors explained how the work of a supervisor included building a framework for equitable leadership practices which facilitated various members of communities working together for the betterment of education. This goal could be achieved if the supervisors made the effort to creatively frame disparities and initiate actions to address topics of race explicitly. In the Indonesian context, where the country is considered as having one of the most diverse communities in the world, this need to address the local context did not seem to be really prioritized at the district level. Nielsen (2003) pointed out that uniformity was so strongly emphasized by Suharto's centralization regime that initiatives and differences were not tolerated. This made education personnel at the district level tend to have similar ways of thinking and operating across the country. As found in a study by Sumintono (2006) in the early part of the country's educational decentralization practice in one municipality, rarely did the district government take on a new initiative. A district officer explained, "In terms of technical matters, such as how is teaching and learning practiced in school, how are examinations conducted, or how supervision is undertaken, most of these have remained the same. We are not brave enough to change all of that" (Sumintono, 2006, p. 134). This situation was also related to the district education officers' capacity, where their experience and expertise were somehow detached from educational activities. The tendency for district level authorities to handle educational issues was similar before the Reform era in Indonesia, and the way they acted under their authority was sometimes in contradiction to the MoEC policy (Zamjani, 2016). 
The situation at the school level

Moving from the district to the school level, the expectation is for principals, as instructional leaders, to take larger parts in shaping the betterment of classroom experiences for students. Different contexts and circumstances lead to the dynamics of what happens at the school level. An interesting comparison in regard to recruitment and how school heads practice their leadership is presented in this section.

One article from Wilkinson et al. (2019) in this special issue illustrated perfectly the selection and recruitment of principals in Catholic Schools in Australia. Previously, district offices appointed principals on the basis of seniority or length of service, but currently they seek principals who can "articulate what was core to [their] thinking about learning and leadership" (Wilkinson et al, 2019). This study showed that, indeed, nurturing instructional leadership at schools should be a key role of the district education office. In addition, Aas and Paulsen (2019), in this issue, highlighted the pathway that produced changes from the "Benchlearning" program at the school leadership level, which included distributed leadership and learning leadership. In particular, distributed leadership that was practiced in overall school organizations led to improvements in teachers' skills in digital learning and formative assessment. Both studies showed that changing principal leadership styles had an impact across the whole school organization that enabled improvement in student learning.

The process of selecting and preparing principals in Indonesia is currently undergoing some interesting developments (Sumintono et al., in press). In the New Order era (the Suharto Administration years between 1966 and 1998), selected teachers who started in the 1980s were requested to join a week of principal preparation training before their appointment, but the content of the training emphasized public administration, and not educational management and instructional leadership (Sumintono et al., 2015). Later, in the early Reform era in 2001, there was a change in principal selection and preparation. The district government, who had full authority in the education sector, changed the landscape drastically; a valid selection process and completion of principal preparation training were not the main criteria for appointing principals for public schools. There were rumors of favoritism due to political ties to the district Major in order for teachers to be selected as school principals. Even when the MoEC released standards of principal competency in 2006 that had to be followed, the standards were downplayed at the local level (Zamjani, 2016).

As a response to the issue, in 2009, the MoEC stipulated Regulation No. 6 Year 2009 on the Organization and Work Procedures of Lembaga Pengembangan dan Pemberdayaan Kepala Sekolah, or Principal Development and Empowerment Agency (Sumintono et al, 2015). This agency was responsible for carrying out the preparation, development and empowerment of school principals as stated in the MoEC standards of principal competency (LP2KS, 2018). The change in the paradigm of education management from centralization to decentralization required school principals to not merely be managers who concentrated more on budget problems and other management issues, but also to be leaders who were able to create a vision and inspire their staff members (Sumintono et al, 2015). Thus, the role of principals as instructional leaders was suddenly essential. In fact, as Firmaningsih-Kolu (2016, p. 80) noted from her research, "[...] the principal plays an essential part in implementing the instructional leadership effectively at school." Instructional leadership also had a positive effect on student outcomes (Jawas, 2014).

Now, selection is first conducted by the local governments; eligible teachers are required to have been at least five years in service and to have a bachelor's degree. The first stage is a week's training at the LP2KS office in Solo, where candidates, among other things, are introduced to instructional leadership theories and practices. The next stage is an apprenticeship for two months in their area, where the candidates serve as teachers and prepare a school development plan. The last stage is presenting the prepared development plan at the LP2KS office (LP2KS, 2018). Sumintono et al. (2015) reported that the LP2KS 
JEA

57,5

training was welcomed by the principal candidates as they believed that the agency would equip them better for their roles. The teachers who passed this training were eligible to be appointed as principals by the district government. The findings from Sumintono et al.'s (2015) study revealed that even though principal training had been standardized in Indonesia, and is now a compulsory part of the principal certification process, micropolitical influences at the district level still currently govern the appointment of public school principals. Ultimately, the district Mayor has the final authority to appoint principals in public schools.

While the changes discussed earlier have helped improve school leadership and the education system in general, school principals' management skills are still somewhat lacking in Indonesia. A study conducted in the New Order era by Jones and Hagul (2001, p. 214) found that typically, school principals in Indonesia "have little authority in running the school or in resource allocation, nor are they usually trained to manage or lead a school well." Moreover, at the beginning of the Reform era in 2002, Mr Malik Fadjar, who was then the Minister of Education, had voiced out that "the Indonesian government did not educate school leaders to be independent in many aspects of school administration" (Sofo et al., 2012, p. 503). Several researchers had portrayed the educational leadership situation as experiencing influences from the district level in different ways. Bjork (2005) examined the curriculum decision making, and management in the education sector in East Java. In his study, he unveiled that school principals were perceived to not have enough capacity in terms of expertise and experience to handle the challenges of leadership and opportunities of autonomy. Professional help from the district level was nearly non-existent for principals; the education sector was under the district government, which itself could possibly be facing the same difficulties, or unsure of how to handle them.

Several studies conducted in the Reform era between 2010 and 2014 indicated that instructional leadership was not the principals' first priority. However, a principal's leadership was crucial as a study in Lampung found that teachers' job satisfaction improved when the principal's style in decision making was less coercive and bureaucratic (Hariri et al., 2014). Similarly, Damanik (2014) observed that the leadership behaviors of principals were deemed to be important for school improvement, that is, the teacher's self-efficacy in the context of education reform. Meanwhile, Jawas (2014) highlighted that instructional leadership by the school principal could support the practices of managing, promoting, improving and assessing instruction. However, the perceptions about teaching and learning of principals and teachers were found to be different among them, and they did not necessarily lead to increased frequency of practices that influenced instructional improvement. The studies by Hariri et al. (2014), Damanik (2014) and Jawas (2014) suggest that principalship in Indonesia has shifted slightly from school management to educational leadership. The shift to instructional leadership practice should be facilitated by the district governments to improve the quality of education in their area.

\section{The way forward}

The seven empirical articles in this special issue show that the change in the supervisor and district education roles facilitates the improvement of principals' instructional leadership at the school level. In the Indonesian context, the historical development and realities of a developing country as discussed above, which show complexities of instructional leadership implementation requiring certain antecedents, cannot be handled easily (Hariri et al., 2016). Improving the capacity of supervisors, for instance, should be a strategic choice, followed by building the partnership between principal supervisors and principals. This work requires antecedents to be in place (e.g., trust, skillfulness and credibility of the principal supervisors, and self-regulated learning of the principals) (Thessin, 2019), which are little known in the Indonesian literature. 
Findings reported in this issue show that districts have to carefully select and prepare supervisors to be able to contribute to a supportive and collegial relationship between supervisors and principals. More importantly, there should be a willingness from the districts to change directions, in that principal leadership in Indonesian schools should not merely emphasize school management, but should also be directed toward instructional leadership and development (Lee and Hallinger, 2012). We would argue that there is a mutual relationship between principals and supervisors in terms of instructional leadership - both principals and supervisors simultaneously support one another to possibly make instructional leadership work effectively.

Educational decentralization in Indonesia has been underway toward the improvement of education quality. This decentralization has resulted in education reforms, one of which is marked by the transfer of administrative powers from the central government to the local governments, particularly at the district and school levels. The aim to improve education quality has brought about a change in how district educational leaders play a role in instructional leadership, including how school principals are recruited. This change is a priority to ensure that the recruited principals can contribute to improving school quality, and accordingly, district-wide education quality.

To achieve this goal of improving school quality, as a developing country, Indonesia, through its district education leaders, needs to engage in policy borrowing, followed by policy learning (Lingard, 2010) by adjusting to the Indonesian school context. Extant research findings have proven that how principal leaders behave in the Indonesian context are generally congruent with descriptions in Anglophile and western literature despite the difference in contexts between Indonesia and developed countries (Hariri et al., 2016). For this fact and other reasons, policy borrowing needs to be attempted by subsequently translating or locally adapting the findings from the seven articles in this special issue to the Indonesian school context (Steiner-Khamsi, 2016). Findings from the seven articles as foreign models could be lessons learned for Indonesian schooling (Phillips and Ochs, 2004).

The idea of policy borrowing, however, was opposed by Harris and Jones (2018) who asserted that policy borrowing does not always work, but policy learning in context does. Therefore, this commentary article would take a stance to advise developing countries, particularly Indonesia, to consider policy borrowing followed by policy learning based on the home context. Ultimately, we need to hold on to what Rigby et al. (2019) claimed, that "there are no easily adopted generalizable practices, rather leadership must productively struggle through iterative cycles, learning from mistakes and boldly taking risks toward improvement."

Bambang Sumintono Faculty of Education, Universiti Malaya, Kuala Lumpur, Malaysia

Hasan Hariri

Faculty of Teacher Training and Education, Universitas Lampung, Bandar Lampung, Indonesia

Piter Joko Nugroho

Faculty of Teacher Training and Education, Universitas Palangka Raya, Palangkaraya, Indonesia

Umi Anugerah Izzati

Faculty of Education, Universitas Negeri Surabaya, Surabaya, Indonesia, and

Joko Sriyanto

Universitas Negeri Yogyakarta, Yogyakarta, Indonesia 


\section{References}

Aas, M. and Paulsen, J. (2019), "National strategy for supporting school principal's instructional leadership: a Scandinavian approach", Journal of Educational Administration, Vol. 57 No. 5, pp. 540-553.

ACDP (2013), School and Madrasah Principals and Supervisors Competencies Baseline Study, Analytical and Capacity Development Partnership and Agency for Research and Developments, Ministry of Education and Culture, Jakarta.

Arsyad, A. (2017), "Analysis of supervisor competencies in implementing school based management towards quality improvement of secondary schools", 9th International Conference for Science Educators and Teachers, Atlantis Press.

Asikin-Garmager, A. (2017), "Indonesian public school principals' enactment of agency within the boundaries set by social systems", unpublished $\mathrm{PhD}$ thesis, University of Iowa, Iowa, available at: https://ir.uiowa.edu/etd/5409 (accessed October 12, 2018).

Aspinal, E. and Fealy, G. (Eds) (2003), Local Power and Politics in Indonesia: Decentralisation and Democratisation, Institute of Southeast Asian Studies, Singapore.

Bennet, R. (2010), Decentralizing Authority after Suharto: Indonesia’s “Big Bang”, 1998-2010, Innovation for Successful Society, Princeton University, available at: https://successfulsocieties.princeton.edu/ sites/successfulsocieties/files/Policy_Note_ID132.pdf (accessed November 15, 2018).

Bjork, C. (2005), Indonesian Education: Teachers, Schools, and Central Bureaucracy, Routledge, New York, NY.

Chapman, C. (2019), "From hierarchies to networks: possibilities and pitfalls for educational reform of the middle tier", Journal of Educational Administration, Vol. 57 No. 5, pp. 554-570.

Damanik, E. (2014), "Principal leadership style and its impact on school climate and teacher selfefficacy in Indonesian schools", unpublished $\mathrm{PhD}$ dissertation, Curtin University.

Firmaningsih-Kolu, Y. (2016), "The role of the principal's instructional leadership at schools in Indonesia”, unpublished master thesis, University of Jyväskylä, Jyväskylä, available at: https:// jyx.jyu.fi/handle/123456789/49654 (accessed October 10, 2018).

Fitriah, A., Sumintono, B., Subekti, N.B. and Hassan, Z. (2013), "A different result of community participation in education: an Indonesian case study of parental participation in public primary schools", Asia Pacific Education Review, Vol. 14 No. 4, pp. 483-493.

Hariri, H., Monypenny, R. and Prideaux, M. (2014), "Leadership styles and decision-making styles in an Indonesian school context”, School Leadership \& Management, Vol. 34 No. 3, pp. 284-298.

Hariri, H., Monypenny, R. and Prideaux, M. (2016), "Teacher-perceived principal leadership styles, decision-making styles and job satisfaction: how congruent are data from Indonesia with the Anglophile and Western literature?”, School Leadership \& Management, Vol. 36 No. 1, pp. 41-62.

Harris, A. and Jones, M.S. (2018), "Why context matters: a comparative perspective on education reform and policy implementation”, Educational Research for Policy and Practice, Vol. 17 No. 3, pp. 195-207.

Honig, M.I. and Rainey, L.R. (2019), "Supporting principal supervisors: what really matters?”, Journal of Educational Administration, Vol. 57 No. 5, pp. 445-462.

Jawas, U. (2014), "Instructional leadership in Indonesian school reform: local perceptions and practices", unpublish master thesis, University of Canberra, Canberra, available at: www. canberra.edu.au/researchrepository/file/ded16a8c-1fb6-4b12-81d7-bf6eb7e5e4d4/1/full_text.pdf (accessed October 20, 2018).

Jones, G.W. and Hagul, P. (2001), "Schooling in Indonesia: crisis-related and longer-term issues", Bulletin of Indonesian Economic Studies, Vol. 37 No. 2, pp. 207-231.

Lee, M. and Hallinger, P. (2012), "National contexts influencing principals' time use and allocation: economic development, societal culture, and education system", School Effectiveness and School Improvement, Vol. 23 No. 4, pp. 461-482. 
Lindsey, T. (2018a), “20 years after Soeharto: Is Indonesia's 'era reformasi' over?", available at: https://pursuit.unimelb.edu.au/articles/20-years-after-soeharto-is-indonesia-s-era-reformasiover (accessed January 12, 2019).

Lindsey, T. (2018b), "Post-reformasi Indonesia: the age of uncertainty", available at: http:// indonesiaatmelbourne.unimelb.edu.au/post-reformasi-indonesia-the-age-of-uncertainty/ (accessed January 12, 2019).

Lingard, B. (2010), "Policy borrowing, policy learning: testing times in Australian schooling", Critical Studies in Education, Vol. 51 No. 2, pp. 129-147.

LP2KS (2018), "Profil LP2KS: Tugas dan fungsi (LP2KS profile: Tasks and functions)", Lembaga Pengembangan dan Pemberdayaan Kepala Sekolah, avaialbe at: http://lppks.kemdikbud.go.id/ $\mathrm{id} / \mathrm{p} /$ tugas-fungsi (accessed October 18, 2018).

Nielsen, H.D. (2003), "Reforms to teacher education in Indonesia: does more mean better?", in Beauchamp, E.R. (Ed.), Comparative Education Reader, RoutledgeFalmer, New York, NY.

Nugroho, R. (2008), Kebijakan Pendidikan yang Unggul: Kasus Pembangunan Pendidikan di Kabupaten Jembrana, 2000-2006, Pustaka Pelajar, Yogyakarta.

Phillips, D. and Ochs, K. (2004), "Researching policy borrowing: some methodological challenges in comparative education", British Educational Research Journal, Vol. 30 No. 6, pp. 773-784.

Rigby, J., Donaldson Walsh, E., Boten, S., Deno, A., Harrison, M.S., Merrell, R., Pritchett, S. and Seaman, S. (2019), "A view from the field: the process of improving equitable systems leadership", Journal of Educational Administration, Vol. 57 No. 5, pp. 484-500.

Sofo, F., Fitzgerald, R. and Jawas, U. (2012), "Instructional leadership in Indonesian school reform: overcoming the problems to move forward”, School Leadership \& Management, Vol. 32 No. 5, pp. 503-522.

Sumintono, B. (2006), "Decentralized Centralism: School Based Management Policies and Practices at State Secondary Schools in Mataram, Lombok, Indonesia”, unpublished $\mathrm{PhD}$ thesis, Victoria University of Wellington, Wellington, availavle at: http://researcharchive.vuw.ac.nz/xmlui/ handle/10063/153 (accessed October 10, 2018).

Sumintono, B., Hidayat, R., Patras, Y.E., Sriyanto, J. and Izzati, U.A. (in press), "Leading and managing schools in indonesia”, in Salleh, H. and Goh, J.W.P. (Eds), Perspectives on School Leadership in Asia-Pacific Contexts, Springer, Dordrecht.

Sumintono, B., Sheyoputri, E.Y., Jiang, N., Misbach, I.H. and Jumintono (2015), "Becoming a principal in Indonesia: possibility, pitfalls and potential", Asia Pacific Journal of Education, Vol. 35 No. 3, pp. 342-352.

Sumintono, B., Subekti, N.B., Mislan, N., Said, H. and Tahir, L.M. (2014), "In Search of the excellent school: a case study of an indonesian international standard school in improving its capacity building", The Asia-Pacific Education Researcher, Vol. 23 No. 3, pp. 565-576.

Suprana, J. (2009), Naskah-Naskah Kompas Jaya Suprana, PT Elexmedia Komputindo, Jakarta.

The World Bank (2018), "Improving teaching and learning in Indonesia", available at: www. worldbank.org/en/country/indonesia/brief/improving-teaching-and-learning-in-indonesia (accessed January 15, 2019).

Thessin, R.A. (2019), "Establishing productive principal/principal supervisor partnerships for instructional leadership", Journal of Educational Administration, Vol. 57 No. 5, pp. 463-483.

Wilkinson, J., Edwards-Groves, C., Grootenboer, P. and Kemmis, S. (2019), "District offices fostering educational change through instructional leadership practices in Australian secondary schools", Journal of Educational Administration, Vol. 57 No. 5, pp. 501-518.

Zamjani, I. (2016), "Dancing with Legitimacy. Globalisation, Educational Decentralisation, and the State in Indonesia”, unpublished $\mathrm{PhD}$ thesis, The Australian National University, Canberra, available at: https://openresearch-repository.anu.edu.au/handle/1885/117190 (accessed October 21, 2018). 


\section{Further reading}

Honig, M. (2008), "District central offices as learning organizations: How sociocultural and organizational learning theories elaborate district central office administrators' participation in teaching and learning improvement efforts", American Journal of Education, Vol. 114 No. 4, pp. 627-664.

Leithwood, K., Sun, J. and McCullough, C. (2019), "How school districts influence student achievement", Journal of Educational Administration, Vol. 57 No. 5, pp. 519-539.

Sumintono, B. (2010), "School-based management policy and its practices at district level in the post new order Indonesia”, Journal of Indonesian Social Sciences and Humanities, Vol. 2, pp. $41-67$. 